\title{
Towards Student Inclusivity during COVID-19: Testing the \#datafree Moya Messenger
}

\section{Fazlyn Petersen \\ ORCiD ID: https://orcid.org/0000-0003-4592-2861}

\begin{abstract}
The coronavirus has highlighted the socio-economic plights of many of our students who are not able to continue learning due to the lack of internet access and the high cost of data. As a result, a large majority of students may be excluded when our learning management systems are not zero-rated. On 15 April 2020, not all Network Providers have zero-rated the University of the Western Cape's iKamva e-learning management system. This has resulted in the need to implement innovative options. This exploratory case study piloted the \#datafree Moya Messenger application which should allow 500 students access to instant messages without having data. The pilot performed ten tests to test the usability and accessibility of the application. Nine of the ten tests were achieved. Findings indicated challenges in the initial implementation of the application to the class and the need to have mobile data or WiFi turned on for use. Despite the intention to keep all students connected, the application was not available to iPhone users, so it was not entirely inclusionary. However, it may still be a more inclusive option than using e-learning systems that are not zero-rated.
\end{abstract}

Keywords: student inclusivity, zero-rated, socio-economic conditions, coronavirus (COVID-19), data-free mobile messenger 


\section{Introduction}

The World Health Organisation reported several pneumonia cases in China on 31 December 2019. The Severe Acute Respiratory Syndrome Coronavirus 2 (SARS-Cov-2) was recognised as the causative agent of the coronavirus disease (COVID-19) (Department of Health: South Africa 2020). On 20 April 2020, Coronavirus has since spread to 213 countries, including South Africa (World Health Organization 2020). The coronavirus has led to a significant number of confirmed deaths, globally (World Health Organization 2020). The coronavirus as led to the unprecedented implementation of an initial 21-day lockdown in South Africa from midnight on Thursday, 26 March 2020. The initial lockdown was a avoid 'an enormous catastrophe' among the population (Department of Health: South Africa 2020). Lockdown was further extended by another two weeks on 9 April 2020 (Ramaphosa 2020).

As a result, South African tertiary institutions implemented early recess and vacated students in residences by 20 March 2020 (Nzimande 2020). All institutions were requested to complete a survey to determine their IT capability for offering online learning (Nzimande 2020). The results were due to be analysed by the 27 March 2020, to identify institutions who required immediate assistance. The Minister of Higher Education, Blade Nzimande, has recognised that institutions and students have differing levels of capabilities and access to devices which will impact the implementation of online learning (Nzimande 2020).

Evidence indicates that despite the penetration of mobile phones only $10.4 \%$ of South Africans had internet access at home in 2018 (Statistics South Africa 2018). Internet access is higher households in metropolitan areas $(17.3 \%)$ compared to only $1.7 \%$ of rural households having internet access (Statistics South Africa 2018). Statistics South Africa (2018) indicates that households are more likely to have internet access at work, educational institutions or at Internet cafés. Therefore, interventions to achieve online learning must be carefully tailored to be effective, affordable and accessible to the South African population, especially for groups with low socio-economic status.

The inclusion of all students is supported by the Sustainable Development Goal 3: 'quality education for all' (United Nations 2015). South Africa's White Paper 6 has recognised an important fact that applies to all learners: 'particular life experiences or socio-economic deprivation' may lead to learners not learning effectively or may lead to the exclusion from the 
learning system (Department of Education 2001:7). While South Africa's White Paper 6 predominantly focuses on the inclusion of learners with special needs, this paper focuses 'inclusive education is a movement against exclusion of any kind and a reaction to political segregation and social inequality' (Gudjonsdottir and Óskarsdóttir 2015:2).

The increased pervasiveness of information communication and technology (ICT), such as mobile phones, and increasing internet access shows promise for delivering quality education for all. The use of ICT in education is often referred to as electronic learning (e-learning) or online learning of which mobile learning (m-learning) is a sub-segment (Moore, Dickson-Deane \& Galyen 2011). M-learning refers to e-learning applications that are accomplished with the help of mobile technology (Nirgude \& Naik 2017).

Learning management systems (LMS) that uses the internet to enable online learning has become widely used since the end of the 1990s (Solomon 2017). LMS allows an easy way for lecturers to upload learning resources, creating tests and assignments, monitor progress and enables the communication between lecturers and students (Solomon 2017). However, the potential of LMS to provide quality education for all will only be realised if the necessary infrastructure to provide internet access exists.

In South Africa, infrastructure and access to the internet are governed by South Africa's National e-Strategy. The strategy encompasses seven key areas:

1. Enabling policies: South Africa's ICT and related policies should be forward-looking, transparent and predictable to enable inclusive growth and development.

2. Infrastructure: The digital society will be underpinned by the availability of infrastructure throughout the country. Interventions are thus needed to stimulate both the public and private sector investments building on SA Connect and the introduction of supply-side interventions to promote competition and SMME development in the telecommunications and broadcasting industries.

3. Universal access: all South Africans should have access to affordable user devices and high-quality services irrespective of geography and social status. 
4. Security: Citizens should trust the ICT environment, knowing that their information and transactions are protected.

5. Content: South Africans should be involved in the development of local content taking advantage of the global nature of the ICT sector. There is a big scope for South Africa to emerge as one of the leading content industries on the continent and in the world. This must be supported by strong and affordable content rights management.

6. Innovation: Innovations should be geared toward growing the ICT sector while simultaneously introducing ICT enabled solutions in other key sectors of the economy. Government and society as a whole should focus on the development of local intellectual property and knowledge to encourage local production and manufacturing.

7. Skilling the nation: A comprehensive skills development programme will create awareness and explain technologies to improve the uptake and usage of ICTs in societies (Department of Telecommunications and Postal Services: Republic of South Africa 2017).

Skilling the nation has effectuated the implementation of a South African National e-Skills Plan of Action (NeSPA) 2012 with the aim of 'Continuing eSkilling the Nation for Equitable Prosperity and Global Competitiveness in the Knowledge Society' (Department: Communications 2012). Despite the National e-Strategy considering infrastructure (Department of Telecommunications and Postal Services: Republic of South Africa 2017), a strategy does not always translate into ecosystems, such as e-learning, that are operationally effective at a national level.

The problem was highlighted by the Deputy Higher Education Minister, Buti Manamela, who expressed his dismay at institutions who are resuming their academic programmes online on Monday 20 April 2020. He stated in an interview,

No student should be left behind. Students who have no study gadgets or internet connectivity should not be treated as though they are the cause of \#Covid_19. We will ensure that we take all students along (Khumalo 2020). 
He further indicated that teaching online would exclude students from 'poorer background' (Khumalo 2020). Hence, the objective of this study to construct and test an inclusive technological design in higher education.

\section{Inclusive Design in Higher Education Model}

South Africa is referred to as the 'rainbow nation' and this is based on the diversity of our people. Evidence indicates that inclusion is dependent on an institutional commitment to addressing the needs of the increasing numbers of diverse students (Lawrie et al. 2017). Therefore, inclusivity must be cognisant of the diversity of students that can be based on:

- Educational diversity - skills, abilities, educational experience, knowledge;

- Dispositional diversity - identity, awareness, expectations, awareness;

- Circumstantial diversity - Access to ICT, financial situation, geographical location and

- Cultural diversity - Language, ethnicity, religion, social background (Morgan \& Houghton 2011).

All four of these diversity factors apply to South African students and will need to be considered when implementing an inclusive technological design in higher education.

Models of inclusivity indicate a need to transition from assimilation (students integrated into an existing system) to making alternative provision (separate policies and practices for particular individuals or groups). The final transition moves towards an inclusive culture (flexible policies and practices focusing on the success of all students) (Al-Khamisy 2015).

Lawrie et al. (2017:5) highlight the methods for creating inclusivity through using inclusive pedagogies:

- pedagogies should meet the diversity of learners' needs, and should not create barriers for particular students or student groups;

- pedagogies should enable accessibility and be crafted through consultation amongst a variety of institutional stakeholders; 
- assessment should be multimodal and flexible while maintaining academic standards;

- institutions should adopt a more holistic, comprehensive approach to supporting teaching and learning for diverse groups of learners.

The view of including a transformative pedagogy in the inclusive design for higher education is supported by Wood (2015).

\section{Research Model}

Wood's (2015) Inclusive Design in Higher Education model also includes the use of Information Communication and Technology (ICT), which is important for the continuation of learning during the Covid-19 lockdown period. The factors most applicable to this research, namely: institutional factors, individual factors, programme factors, accessibility, usability and personalised learning have been used to create the research model (refer to Figure 1). Each inclusion is discussed in further detail below.

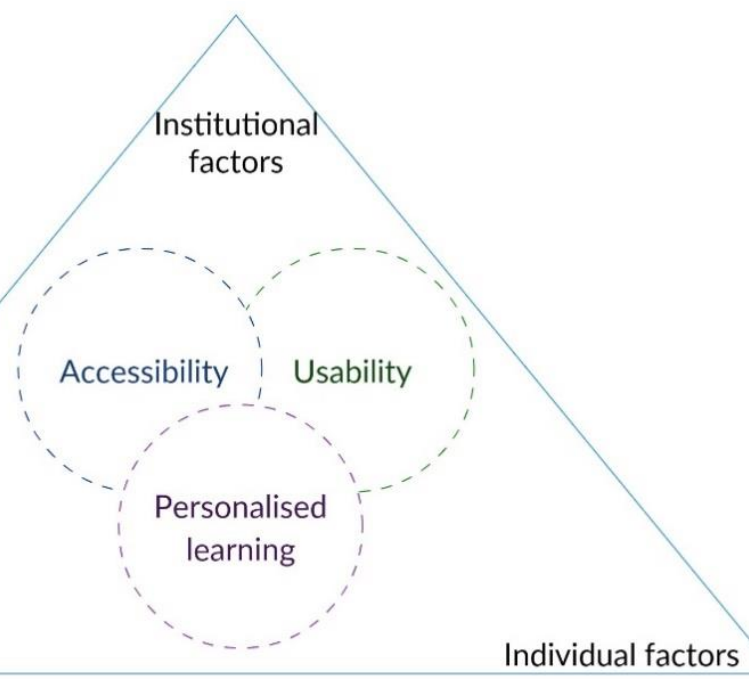

Figure 1 Research model based on Wood (2015) 


\section{Institutional Factors}

The University of the Western Cape (UWC), has a

history of creative struggle against oppression, discrimination and disadvantage. UWC's key concerns with access, equity and quality in higher education arise from extensive practical engagement in helping the historically marginalised participate fully in the life of the nation (University of the Western Cape 2019).

The University has recognised that not all students can engage in online teaching due to a lack of computer devices. Therefore, UWC has launched a crowdfunding appeal, \#NoStudentWillBeLeftBehind, to raise funds to purchase computer devices for approximately 7500 students. The allocation of devices to students will be based on the University's need's assessment (University of the Western Cape 2020a).

The provision of devices for students at need will be assisted by the Centre for Innovative Education and Communication Technologies (CIECT) at UWC. CIECT has supported the adoption of innovative e-learning practices (Stoltenkamp 2019). iKamva (Sakai) is the implemented e-learning platform. iKamva is an IsiXhosa phrase which means: 'moving forward, the future' (Stoltenkamp 2019). The iKamva platform allows for lecturers to interact with students through the use of tools, such as tests and quizzes, calendar and course resources (University of the Western Cape 2020b).

IKamva mobile application, the mobile learning management systems, is also available to UWC students (Petersen 2020). The use of the iKamva mobile application was found to be low (24.6\%) among third-year Information Systems students, with a preference for using the e-learning platform (Petersen 2020). However, on 15 April 2020, not all Network Providers have zero-rated the University of the Western Cape's iKamva learning management system. Therefore, students would need reliable internet access at home or sufficient funds to purchase data. Based on Statistics South Africa (2018), this may lead to the exclusion of a potentially significant student population.

\section{Programme Factors}

Programme factors are likely to differ across degrees and universities. UWC has seven faculties, such as Arts, Community and Health Science, Dentistry 
and Economic and Management Science (EMS). Programmes included certificate options as well degrees (University of the Western Cape 2020c). The differences in programmes are likely to impact the implementation of online learning.

Training must be provided to academic staff who are not familiar with online learning. It cannot be expected that a sudden change to online learning for programmes that are traditionally taught face to face will be seamless. Hence, New York University moved classes with the highest enrolments online first and also determined which courses could not use this medium (The Chronicle of Higher Education 2020).

Programmes cannot run in isolation and there is still a need to provide forms of programme administration. Examples of the required administration may be deregistering students from programmes who will be unable to engage in online learning. Research indicates that academic or administrative work can be done in isolation or by using remote consulting (Cao et al. 2020).

However, the literature supports that demographics and individual instructor differences are the prominent factors that may influence the success of online learning (Fish \& Snodgrass 2018). Programme factors shown to influence instructor perspectives on online education includes 'program difficulty, interaction between students and instructors, interaction between the student and the instructor, cheating and technology preference' (Fish \& Snodgrass 2018:15). These programme factors must be considered when designing an inclusive model.

\section{Individual Factors}

Programme factors alluded to the importance of considering student demographics. The exclusion of South African students is based on the fact that more than $50 \%$ of students enrolled in the higher education system are from disadvantaged, black, working-class households who reside in townships or villages (Mzileni 2020). This demographic is evidenced by a significant percentage of students who are dependent on the National Student Financial Aid Scheme (NSFAS) (Mzileni 2020).

The pandemic has also raised the need to address mental health and well-being, with students in China suffering from higher levels of psychological distress (Ho, Chee \& Ho 2020). Evidence indicates that increased anxiety in Chinese college students was caused by 'economic effects, 
and effects on daily life, as well as delays in academic activities' (Cao et al. 2020:1). The view is supported by a quote from a University of Cape Town (UCT) student,

What's stressing me is the fact that it's my final year, I obviously set goals for myself now I'm not sure anymore ... I wanted to do really well this year so that applying (for jobs) is easy for me next year, now this whole setup is discouraging (Mofokeng 2020).

Lockdown is also resulting in isolation from others during the learning process that can reduce motivation (Osguthorpe \& Graham 2003). The statement is evidenced by a quote from a UCT student,

My problem is that I tend to procrastinate a lot, on campus I avoid that by going to the labs and getting some work done before I head home (res), now I'm stuck at home (Mofokeng 2020).

However, it is noted that 'ICT can have a positive impact on learners in further education in areas such as student motivation, retention, attendance and attainment' (Walker \& Logan 2009:13).

Also, $18.1 \%$ of the South African population lives in informal - or traditional dwellings (Statistics South Africa 2018). Informal- or traditional dwellings frequently have limited or no access to water and electricity. However, 'having adequate access to appropriate forms of energy is critical for improving living standards, health and reducing poverty' (Statistics South Africa 2015). The following quote from a UCT student supports this point,

It's depressing. I hope it won't take that long for UCT to open because the living situation at home is not conducive to studying (Mofokeng 2020).

\section{Personalised Learning}

Online learning provides asynchronous education as students can learn at a time and place that is convenient for them, without having to be present on campus. Therefore, it allows students the ability to personalise their learning (Orfanou, Tselios \& Katsanos 2015). The use of m-learning and e-learning 
allows students to access educational content, regardless of time and location. However, without zero-rating, the use of m-learning and e-learning are not viable options as they will not be accessible to all students.

However, UWC's iKamva platform allows for synchronous- and asynchronous engagement. Asynchronous engagement is usually less dataintensive as learning does not have to occur in real-time. An example of asynchronous engagement on iKamva is discussion forums (University of the Western Cape 2020b). Discussion forums allow for lecturers to post topics, related to course work. Students can post responses at a time that is most convenient for them. Lecturers can set a due date for submission and discussion forum posts may be allocated a grade book. Lecturers and fellow students can provide feedback on responses. The feedback allows for lecturer and student engagement. Additionally, responses can be used as a form of assessment when used in combination with the grade book (CEICT 2019).

Synchronous engagement may be more suitable for students who require immediate responses and feedback. Synchronous engagement allows for real-time interaction and can be implemented through the use of tools such as Google Hangout and iKamva's BigBlueButton. However, the use of synchronous engagement comes at the expense of higher data costs and may result in students being excluded.

\section{Accessibility}

Friemel (2016) contends that internet access is strongly correlated to sociodemographic factors such as income, education, age and gender. A 'digital divide' results from disparities in these factors: the digital divide refers to the gaps in digital technology that lead to social exclusion and the unequal distribution of resources and life chances (Friemel 2016). Therefore, the implementation of online learning may not be accessible to the South African population who experiences 'technological forms of exclusion' as well as educational and income inequalities (Gillwald, Mothobi \& Rademan 2017). Therefore, the resulting digital divide between rich and poor is notable (Gillwald, Mothobi \& Rademan 2017), a divide which likely hinders the achievement of quality education.

Given the need to find more accessible alternatives to LMS, the use of a mobile instant messenger (MIM) was considered. The consideration is based on the MIM serving as a substitute for a LMS (Pimmer et al. 2019) and the 
growing number of MIM users, such as WhatsApp, in South Africa. WhatsApp in South Africa has overtaken Facebook as the most active social media platform (Kemp 2019). The literature indicates that the MIM in education allows for 'temporal [anytime and anywhere], user-friendly, minimal cost, and multi-modality features' (Tang \& Hew 2017:85). The uses of MIM in education includes 'journaling, dialogic, transmissive, constructionist with peer feedback, helpline, and assessment' (Tang \& Hew 2017:85).

\section{Usability}

The literature indicates an interrelationship between accessibility and usability (Wood 2015). International Organization for Standardization (ISO), 1998 defines usability as 'the extent to which a product can be used by specified users to achieve specified goals with effectiveness, efficiency and satisfaction in a specified context of use' (Wood 2015).

Usability is a success factor in e-learning as it improves students' learning experience and the achievement of learning outcomes (Meiselwitz \& Sadera 2008; Pangestu \& Karsen 2017). Literature indicates that if a system does not save users time and effort then it reduces the likelihood of the system being used (Venkatesh et al. 2003).

M-learning may have usability constraints due to mobile phones having smaller screens (Zhang, Zhang \& Halstead-Nussloch 2014). Petersen (2020) indicated that students preferred using iKamva e-learning platform as opposed to the m-learning application for this reason.

The integration of a user-friendly MIM, WhatsApp, as the LMS for students who live in remote areas in Ghana, shows promise for overcoming contextual difficulties faced in online learning. However, even incorporating a MIM such as WhatsApp, will exclude students without internet access or money to purchase data.

\section{\#datafree Moya Messenger}

Based on the research model, the literature indicates the need to take institutional-, programme- and individual factors into consideration when implementing an accessible and usable alternative to all students. The use of MIM, such as WhatsApp, as an option could be considered. The literature indicates that the use of WhatsApp as a learning tool at the university level is 
a viable option. The benefits of using WhatsApp in education include that the application is user-friendly, cost-efficient and provides multi-modality features (Tang \& Hew 2017). The predominant uses of WhatsApp in education include 'journaling, dialogic, transmissive, constructionist with peer feedback, helpline, and assessment' (Tang \& Hew 2017:85). A study tested WhatsApp in remote areas in Ghana, with limited internet access and electricity, and found that it assists distance learning (Koomson 2018).

Despite the benefits of using MIM in education, there are challenges experienced. Challenges include 'device ownership, internet access, improper language use and interference with private lives' (Tang \& Hew 2017:85). However, the Ghanaian study evidenced that,

... a blended mobile learning context is not a nuisance to students, rather it is a 'helpmate' to help resolve many of the contextual difficulties that plague them in a distance learning situation in Ghana (Koomson 2018:45).

Despite the positive outcomes of implementing WhatsApp for educational purposes in Ghana, it must be noted that South African data prices are significantly higher than most of Africa (Healing 2019).

Therefore, in South Africa, using MIM may not achieve the desired level of inclusivity among students with a low socio-economic status who can not afford to purchase data. As a result, this research examined the use of a South African MIM, Moya Messenger. Moya Messenger allows users to communicate via text messages, without incurring data cost. However, users will incur data charges for sending attachments and will be exposed to marketing (Businesstech 2018).

Moya Messenger provides the following functionality:

- Unlimited text: $100 \%$ \#datafree*

- Group chat \#datafree.

- Discover a growing range of \#datafree content and services, all in the one app.

- End-to-end security: automatic end-to-end encryption of all messages.

- Message attachments: fully supported, but not \#datafree** 
- Contacts: automatically find contacts who have Moya.

- Always logged in: never miss a message.

- Offline messages: messages saved when your phone is off.

- No data charges for text messages when you use a SIM card from a supported mobile network.

Attachments are fully supported, such as photos, videos, documents etc. However, sending attachments is not \#datafree. Before sending you will be warned you need mobile data or WiFi' (biNu 2020a).

Moya Messenger uses their reverse billing agreements with MTN, Vodacom, Cell $\mathrm{C}$ and Telkom to provide the free messaging service (Businesstech 2018). The Moya Messenger application has a growing user base. The application is actively used by over one million South African every month and 650000 users every day (Rajgopaul 2019). Users also have access to data-free content such as Wikipedia, 'Cosmopolitan magazine, Assupol Insurance, iQ Academy, Adzuna Job Search, Sanlam Insurance, DirectAxis and Nivea amongst others' (Rajgopaul 2019).

\section{Research Design}

The research used an exploratory case study. The researcher aimed to gain a better understanding of implementing a data-free mobile messenger application to improve inclusivity for students during a global pandemic. The case study approach is extensively used for research where the focus is often concerned with the effects and impact of the system, rather than the technical aspects of information system per se (Myers 1997). This research focuses on a single case of testing the Moya Messenger application during the Covid-19 pandemic.

A case study may be used exploratory research and attempts to capture the meaning in an interactional experience (Myers 1997). The study used tests conducted in a lecturer group to assess whether the Moya Messenger application would be a viable option to use in larger, more diverse students groups located in urban and rural locations.

The data collection for a case study utilised two methods. Based on Yin (2003), this study collected evidence from testing a technological artefact, the Moya Messenger application. Additionally, user reviews for the Moya 
Messenger application on the Google Play store were analysed, using the research model themes, to provide more detailed information from actual users. The data will evidence whether the Moya Messenger application will allow for a more inclusive alternative to non-zero-rated LMS.

The timescale required for the case study is short, and the method has been used successfully to investigate the interaction between users and systems. Due to the short research timeframes obtaining ethical clearance to obtain student responses will be completed as the next phase of this research. The research design will aid in providing a better understanding of the viability to use the data free MIM application for educational purposes during a global pandemic, especially for students with lower socioeconomic status. However, a limitation of a case study design is that these results may not be generalised.

\section{Tests}

Based on the research model (Figure 1), the following tests were performed (refer to Table 1).

\section{Table 1 Tests per Research Model Themes}

\begin{tabular}{|c|c|c|}
\hline No & Theme & Test \\
\hline 1 & Accessibility & $\begin{array}{l}\text { Install the \#datafree Moya Messenger from Google } \\
\text { Play store }\end{array}$ \\
\hline 2 & Accessibility & Complete registration \\
\hline 3 & Accessibility & $\begin{array}{l}\text { Use the application with no mobile data or WiFi } \\
\text { switched on }\end{array}$ \\
\hline 4 & Usability & Send a text message \\
\hline 5 & Usability & Send an attachment \\
\hline 6 & Usability & Create a group for lecturers \\
\hline 7 & $\begin{array}{l}\text { Accessibility } \\
\text { and usability }\end{array}$ & Add group members \\
\hline 8 & Usability & Send a voice note to a group \\
\hline 9 & $\begin{array}{l}\text { Personalised } \\
\text { learning }\end{array}$ & $\begin{array}{l}\text { The application is available for use regardless of } \\
\text { time and geographical location }\end{array}$ \\
\hline 10 & Accessibility & Analyse data usage \\
\hline
\end{tabular}


Fazlyn Petersen

\section{Results}

The results of each test are provided in the following section.

\section{Test 1: Installation}

Despite the promise of free instant messages without data, students still require $15.8 \mathrm{MB}$ of data to download the application from the Google Play store https://play.google.com/store/apps/details?id=nu.bi.moya\&hl=en_ZA (refer to Figure 2).

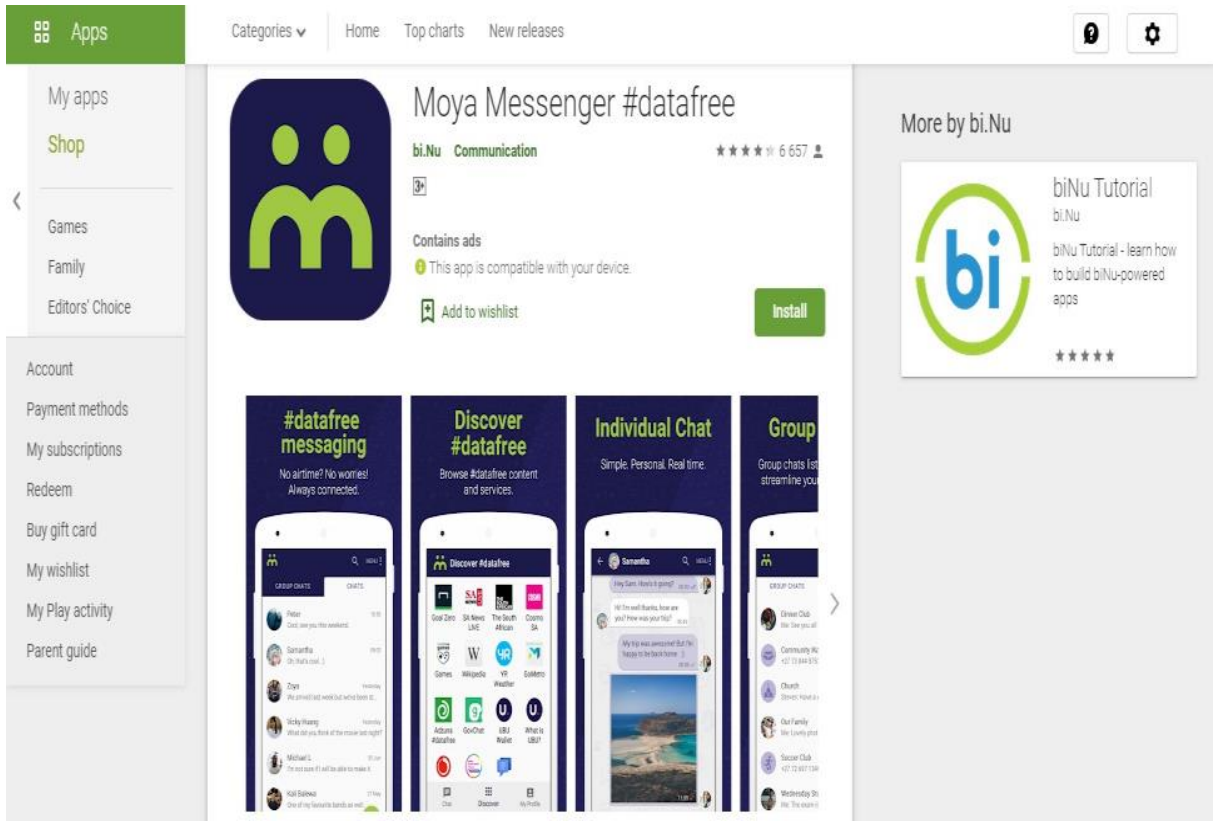

Figure 2: Installing the Moya application

\section{Test 2: Registration}

At the onset, the required registration was also not successful as the server was not available (refer to Figure 3). It required two attempts to successfully 
register on the application. Registration also required air time to receive a onetime pin via SMS (refer to Figure 4).

\section{Figure 3: First attempt to register}

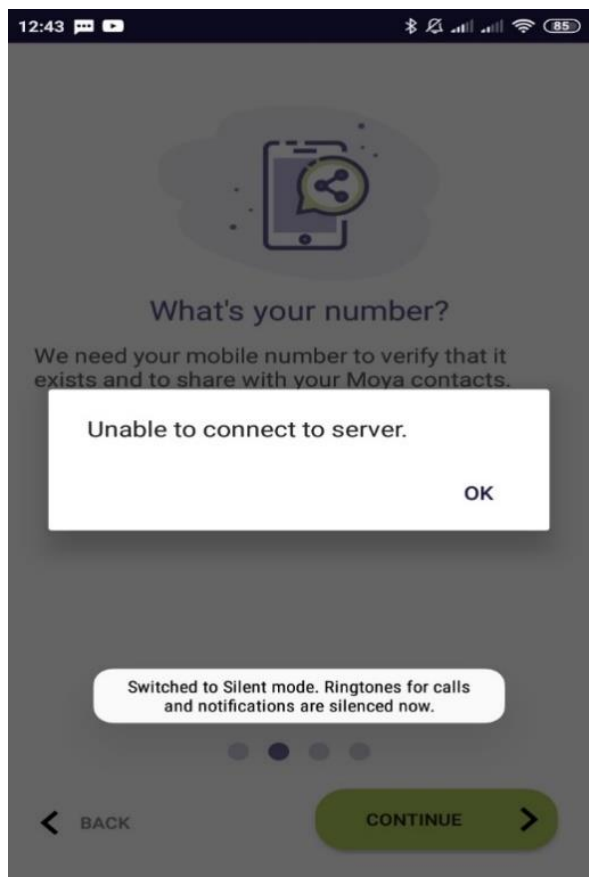

Figure 4: Verification

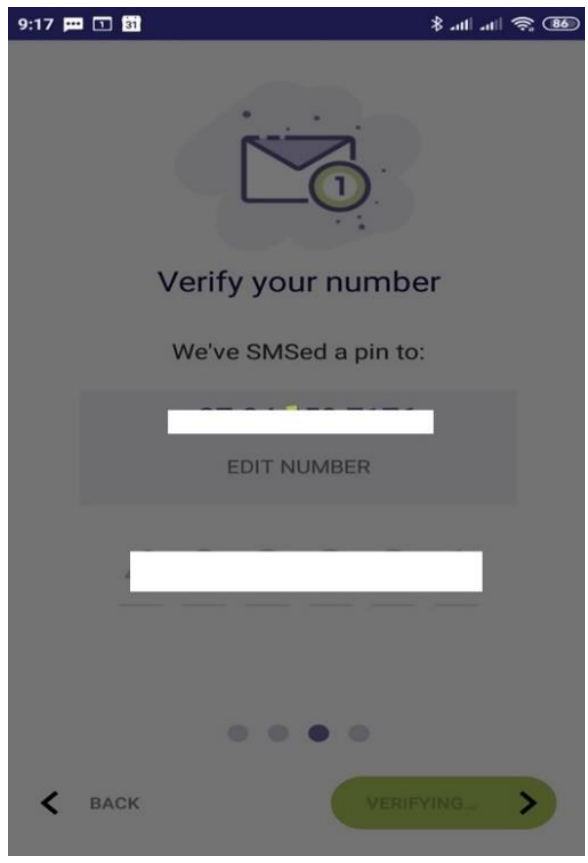

\section{Test 3: No Mobile Data or WiFi Switched On}

To test whether the Moyo Messenger would still function without access to data, mobile data and WiFi were both switched off. The lack of mobile data or WiFi, prevented end-to-end security as the encryption could not be executed (refer to Figure 5).

Messages were also not sent and the application indicated 'waiting' (refer to Figure 7). Messages were sent when either mobile data or WiFi was switched 
back on. The results indicated that despite no data being required to send messages, mobile data or WiFi have to be turned on. There is still a need to have a reliable internet connection.

\section{Figure 5: Setting up encryption}

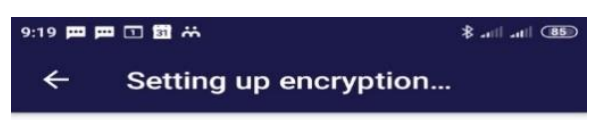

\section{Figure 6: No mobile data or WiFi switched on}

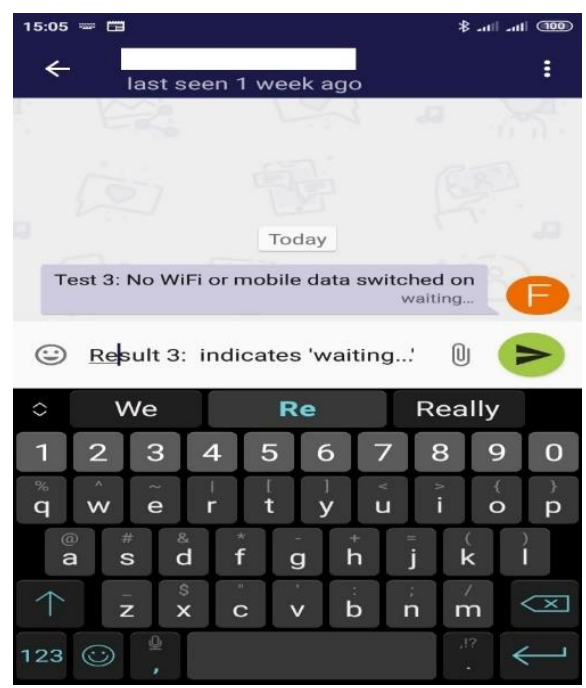

\section{Test 4: Send a Text Message}

The Moya Messenger interface is simple to use. The green arrow button to send and the paper clip to add attachments. The interface is similar to other MIMs, such as WhatsApp, so there should be a seamless transition for WhatsApp users to the Moya Messenger application (refer to Figure 7).

Moya Messenger also indicates via a $\checkmark$ whether a message has been delivered and the time. It also indicates whether all sent messages have been read by the 
recipient. Fellow lecturers indicated that the text message delivery time was fast when mobile data was activated.

\section{Test 5: Send an Attachment}

Figure $\mathbf{8}$ indicates the attachments that may be sent. A notice provides a reminder that sending attachments are not \#datafree. Attachments are not automatically downloaded and receivers are notified of the size of the attachment (refer to Figure 9). Therefore, users can decide if they wish to download the attachment. Hence, there is more control over the amount of data that is being used by this application.

Sending attachments in the lecturer group was an easy and efficient process. However, sending and downloading attachments required data which could still result in students being excluded from obtaining course-related content.

Figure 7: Send a text message

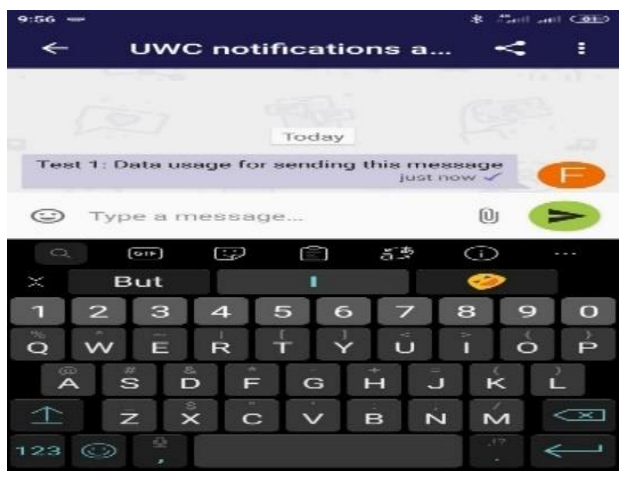

Figure 8: Send an attachment

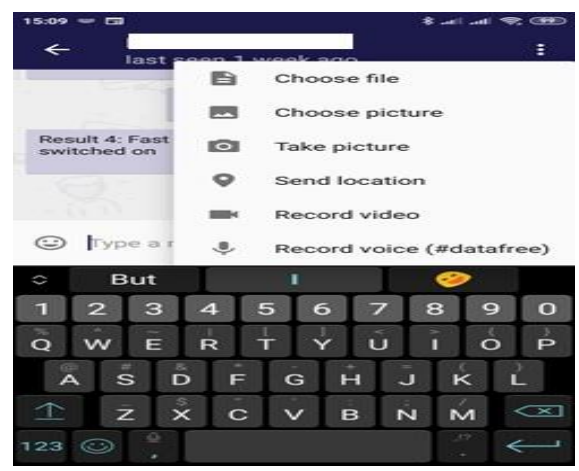




\section{Figure 9: Receiving an image attachment}

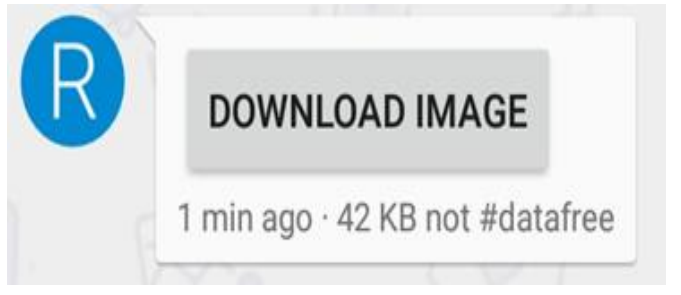

\section{Test 6: Create a Group}

The Moya Messenger application will allow lecturers to create groups for their programmes (refer to Figure 10). The application allows lecturers to create a read-only site, this will not allow students to post messages. It will serve the same purpose as posting an announcement on iKamva or creating an Adminonly group on WhatsApp.

Selecting the read-only option will limit lecturer and student engagement but allows important announcements to be sent quickly. The read-only option will provide a mechanism for posting important information only and limiting the discussion on the items posted.

Making the group public allows access to everyone and the link may also be shared. However, this increases the risk of non-registered students accessing the group.

\section{Test 7: Add Group Members}

The safest method is to add students individually (refer to Figure 11). Moya Messenger allows you to search for users and then add them. If students are not using the Moya Messenger, it allows lecturers to share a link so that they can join. However, this could be a time-consuming task, especially for large groups of students. The alternative is to delegate the addition of student numbers to tutors, if this is a viable option. 
Figure 10: Create a Group

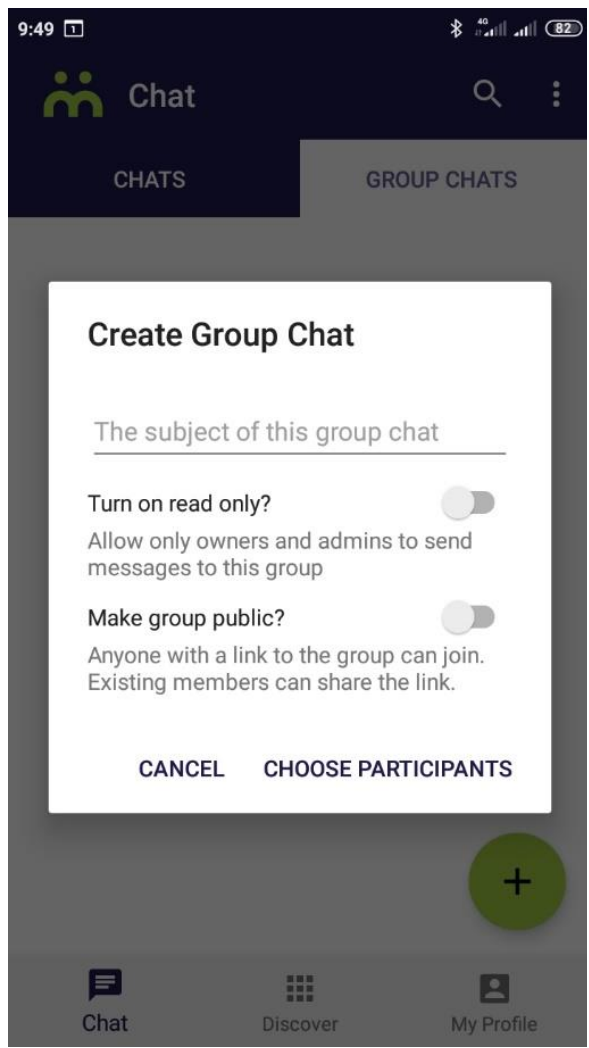

Figure 11: Add a Group Member

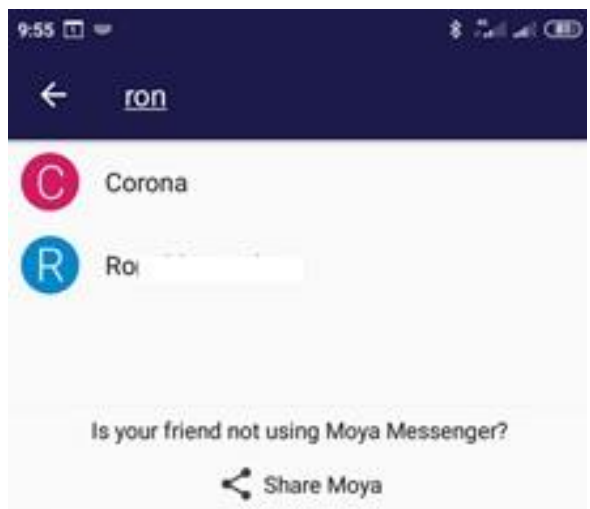

\section{Test 8: Send a Voice Note to a Group}

$\mathrm{BiNu}$ (2020) indicates that attachments are not \#datafree, although 'record voice' was indicated as \#datafree in Figure 8. The label for the 'record voice' attachment has been changed and a warning is displayed to indicate that it is not data-free (refer to Figure 12).

However, sending a short voice note was not data intensive. Data is also required by the receiver to download the voice note. The voice note sent to the lecturer group indicated that voice note sound quality was satisfactory. 
Test 9: The Application is Available for Use Regardless of Time and Geographical Location

The application should be available in all areas where there is access to WiFi or a mobile network (refer to Figure 13). The functionality of Moya Messenger also allows for messages to be saved when your phone is off. Therefore, it should provide access even in more rural locations.

However, the testing for the lecturer group may highlight that the Moya Messenger application is more efficient for this group as lecturers had better network connectivity in urban areas than students may have in more rural areas.

Figure 12: Send a voice note to a group
Figure 13: The application is available for use regardless of time and geographical location

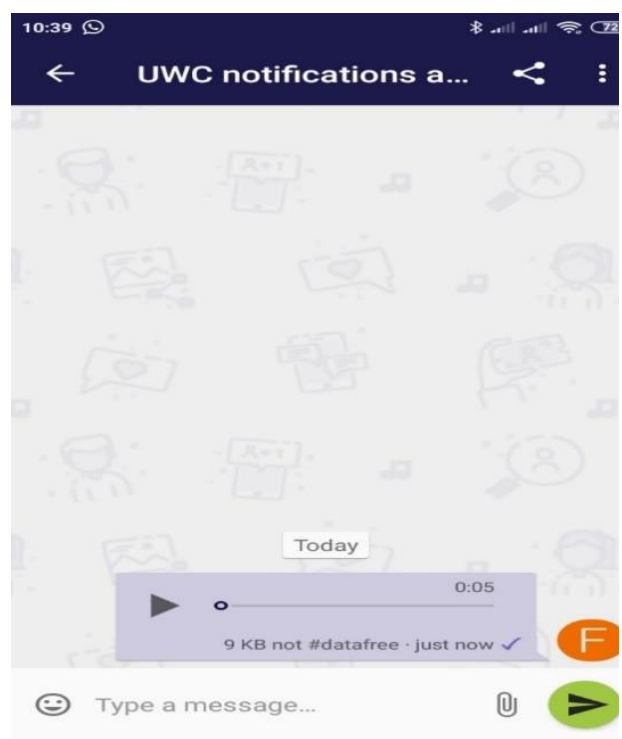

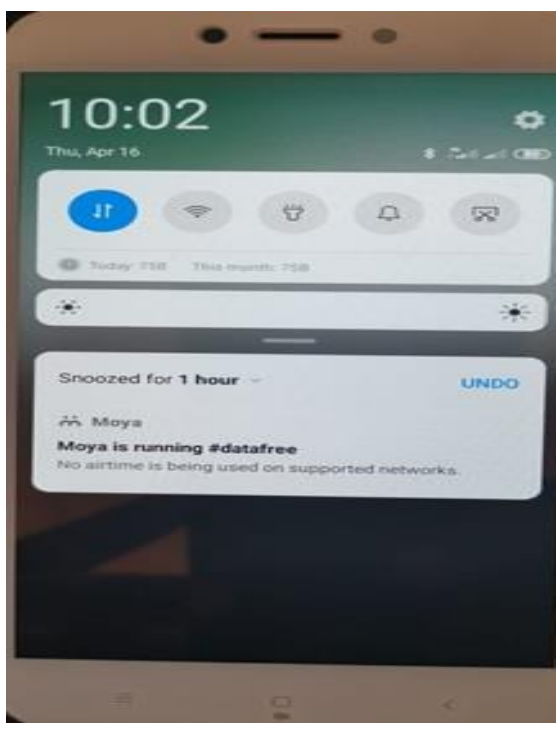




\section{Test 10: Analyse Data Usage}

Figure 14 indicates the data usage by the Moya Messenger application (64.5 $\mathrm{KB}$ ). No data was used to send \#datafree text messages but data was used to create the group, to send attachments and to download attachments.

Compared to WhatsApp, where there is also no automatic download of attachments, (166.4 KB), Moya Messenger used less data even with the download of a picture and voice attachment (refer to Figure 15).

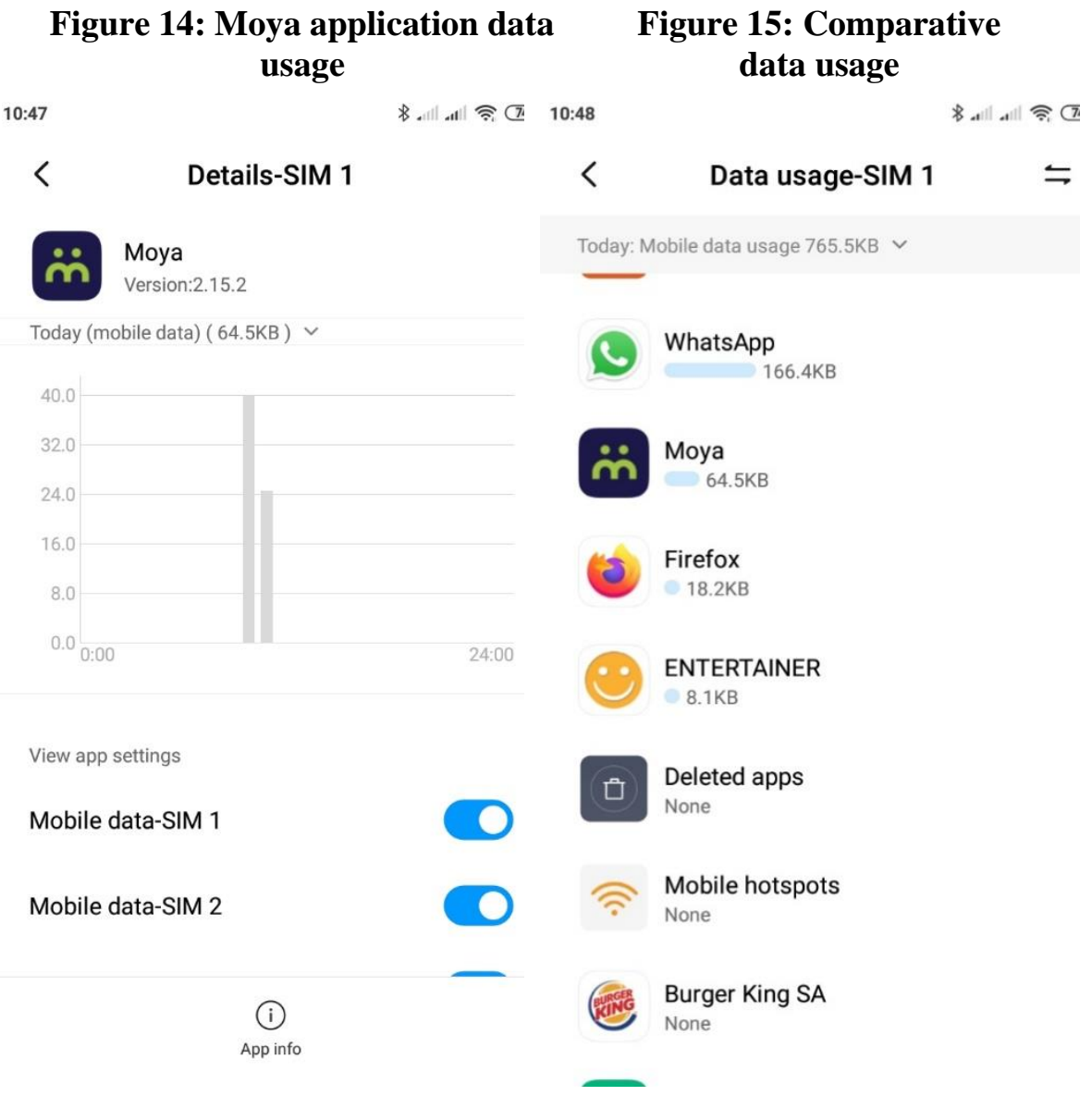




\section{User Reviews on Google Play Store}

The Moya Messenger application obtained a 4.2 out of 5 rating from 9012 reviews (biNu 2020b). Comparatively, WhatsApp messenger received a 4.3 out of 5 rating but had substantially more reviews (116 102 165) (WhatsApp Inc. Communication 2020). Table 2 displays reviews for the Moya Messenger application on the Google Play store, retrieved on 6 July 2020 (biNu 2020b). Results were sorted by 1-star to identify the most critical feedback and by 5star to highlight the most complimentary feedback. The reviews were analysed using the themes from the research model and to expand the findings from the test runs.

User reviews were corrected for grammar and punctuation to improve readability e.g. 'i' was corrected to 'I'.

\section{Table 2: Google Play User Reviews}

\begin{tabular}{|c|c|c|}
\hline Test & Critical 1-star reviews & $\begin{array}{l}\text { Complementary } 5 \text {-star } \\
\text { reviews }\end{array}$ \\
\hline $\begin{array}{l}\text { Test 1: } \\
\text { Installation }\end{array}$ & $\begin{array}{l}\text { An analysis of reviews } \\
\text { indicated that there were } \\
\text { users who experienced } \\
\text { problems with the } \\
\text { installation of the } \\
\text { application. Charlene } \\
\text { Dullisear } 04 \text { June } 2020 \\
\text { provided the following } \\
\text { critical review that resulted } \\
\text { in her deleting the } \\
\text { application, 'I installed the } \\
\text { app but when I put in my } \\
\text { phone number it kept } \\
\text { saying could not g[e]t a } \\
\text { stable con[n]ection it whent } \\
\text { on for ova [over] } 2 \text { hours } \\
\text { eventual[l]y I deleted the } \\
\text { app waist [waste] of datak'. }\end{array}$ & $\begin{array}{l}\text { There were no reviews } \\
\text { regarding installation } \\
\text { specifically although a } \\
\text { review by Sune Brits } 16 \\
\text { April } 2020 \text { indicated, 'I } \\
\text { love it cose-[because] I } \\
\text { don't have wifi or data but } \\
\text { now since I have this app I } \\
\text { can talk to all my friends } \\
\text { and, I deleted } 2 \text { of my } \\
\text { games for this ... I LOVE } \\
\text { IT'. The user chose to } \\
\text { install the MIM over games } \\
\text { and could be indicative of } \\
\text { the user not having } \\
\text { sufficient space on her } \\
\text { phone. This may also be } \\
\text { indicative of a less } \\
\text { expensive smartphone. }\end{array}$ \\
\hline
\end{tabular}




\begin{tabular}{|c|c|c|}
\hline $\begin{array}{l}\text { Test 2: } \\
\text { Registration }\end{array}$ & $\begin{array}{l}\text { Reviews indicated that } \\
\text { users also experienced } \\
\text { problems with registration. } \\
\text { This was highlighted by the } \\
\text { following review: Cayden } \\
\text { Layman 08 June } 2020 \text { 'I } \\
\text { cannot get this to work. I } \\
\text { keep getting an 'unable to } \\
\text { establish a secure } \\
\text { connection' message!'. } \\
\text { However, the biNu team } \\
\text { assisted to try and resolve } \\
\text { the problem on the same } \\
\text { day. }\end{array}$ & $\begin{array}{l}\text { There were no 5-star } \\
\text { reviews found for } \\
\text { registration but it can be } \\
\text { assumed that users } \\
\text { providing 5-star ratings had } \\
\text { successfully installed and } \\
\text { registered the application. }\end{array}$ \\
\hline $\begin{array}{l}\text { Test 3: } \\
\text { No mobile } \\
\text { data or } \\
\text { WiFi } \\
\text { switched on }\end{array}$ & $\begin{array}{l}\text { Tumelo Mogale } 15 \text { June } \\
2020 \text { 'This app is a spam } \\
\text { nothing is free once I } \\
\text { turned off my wifi to see if } \\
\text { it's legit it said NO } \\
\text { INTERNET } \\
\text { CONNECTION'. However, } \\
\text { the biNu team provided } \\
\text { assistance and instructions } \\
\text { that despite messages not } \\
\text { using data, mobile data or } \\
\text { WiFi needed to be switched } \\
\text { on. }\end{array}$ & $\begin{array}{l}\text { There were no specific } \\
\text { reviews regarding the need } \\
\text { to switch keep mobile data } \\
\text { or WiFi switched on. } \\
\text { However, the fact that users } \\
\text { were effectively using the } \\
\text { Moya Messenger } \\
\text { application indicates that } \\
\text { users may have read the } \\
\text { installation requirements or } \\
\text { learnt via trial and error. }\end{array}$ \\
\hline $\begin{array}{l}\text { Test 4: } \\
\text { Send a text } \\
\text { message }\end{array}$ & $\begin{array}{l}\text { A review indicated that } \\
\text { using less expensive } \\
\text { smartphones may not work } \\
\text { as efficiently. This was } \\
\text { highlighted by the } \\
\text { following review: Andries } \\
\text { Joubert } 07 \text { June } 2020 \text {, 'I } \\
\text { have a Vodacom kicka }\end{array}$ & $\begin{array}{l}\text { The following reviews } \\
\text { indicate that the application } \\
\text { works for users who may } \\
\text { have access to less } \\
\text { disposable income, such as } \\
\text { pensioners: Johan } \\
\text { Bezuidenhout } 29 \text { June } \\
\text { 2020, 'This is a great app }\end{array}$ \\
\hline
\end{tabular}




\begin{tabular}{|c|c|c|}
\hline & $\begin{array}{l}\text { phone, not big. Most of the } \\
\text { time the writing of the logs } \\
\text { is so small I can see } \\
\text { nothing.. logically suppose } \\
\text { to be the same size } \\
\text { irrespective kind of phone... } \\
\text { settings only increase [the] } \\
\text { size of letters of chat } \\
\text { message'. }\end{array}$ & $\begin{array}{l}\text { for as me pensioner, thank } \\
\text { you, thank you, thank } \\
\text { you,...now I can talk to my } \\
\text { grandchildren the whole } \\
\text { day!!'. } \\
\text { Younger users, as indicated } \\
\text { by their profile picture, also } \\
\text { echoed this sentiment: } \\
\text { Dolly Mpangazitha } 23 \text { June } \\
\text { 2020, 'I like it so much that } \\
\text { when I am even broke, I } \\
\text { manage to send important } \\
\text { messages and chat with } \\
\text { friends'. }\end{array}$ \\
\hline $\begin{array}{l}\text { Test 5: } \\
\text { Send an } \\
\text { attachment }\end{array}$ & $\begin{array}{l}\text { A critical review indicated } \\
\text { that users would like } \\
\text { attachments to be data free } \\
\text { as well. This is evidenced } \\
\text { by Loretta Smith } 13 \text { June } \\
2019 \text {, 'it is not cool at all I } \\
\text { have introduced so many } \\
\text { people to this application } \\
\text { but you cannot send any } \\
\text { attachments if you do not } \\
\text { have data or wi fi yet you } \\
\text { advertise free can you } \\
\text { please explain'. However, } \\
\text { the Moya Messenger } \\
\text { application indicates that } \\
\text { sending attachments are not } \\
\text { \#datafree. }\end{array}$ & $\begin{array}{l}\text { A complementary user } \\
\text { review by B Lbard } 22 \text { April } \\
2020, \text { '... Love that it } \\
\text { indicates [the] amount of } \\
\text { data used with images etc.' } \\
\text { appreciated that even if } \\
\text { sending were not data-free } \\
\text { you were able to check the } \\
\text { amount of data before } \\
\text { downloading. } \\
\text { However, Red dust } \\
\text { International } 17 \text { June } 2020 \text {, } \\
\text { also echoes the critical } \\
\text { review for attachments to } \\
\text { be data free as well, 'Very } \\
\text { good, just the attachment } \\
\text { part must be sorted out, } \\
\text { data-free } \\
\text { goo \& \& of'. }\end{array}$ \\
\hline
\end{tabular}




\begin{tabular}{|c|c|c|}
\hline $\begin{array}{l}\text { Test 6: } \\
\text { Create a } \\
\text { group }\end{array}$ & 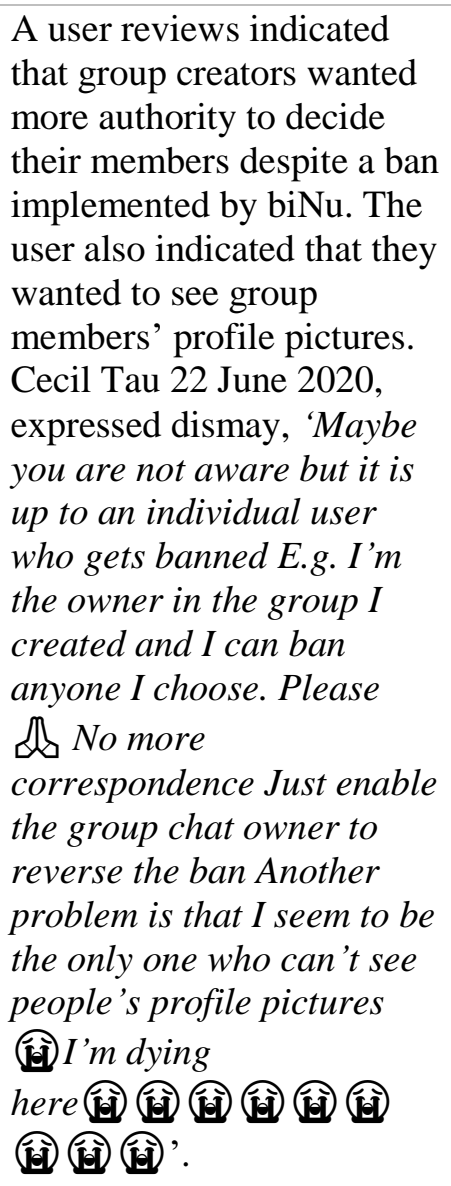 & $\begin{array}{l}\text { A complimentary review by } \\
\text { Randall Jacobs } 16 \text { June } \\
2020, \text { '... to make a group } \\
\text { is easy thought it would be } \\
\text { hard [difficult], nice app' } \\
\text { indicates the ease of setting } \\
\text { up a group. However, there } \\
\text { is no indication of the } \\
\text { group size. } \\
\text { Dr Eric Dilima } 19 \text { April } \\
\text { 2020, 'From [now] } \\
\text { onwards, my church } \\
\text { members must all use this } \\
\text { app for group chats, I love } \\
\text { it' provides evidence for } \\
\text { use among community } \\
\text { groups, such as churches. }\end{array}$ \\
\hline $\begin{array}{l}\text { Test 7: } \\
\text { Add group } \\
\text { members }\end{array}$ & $\begin{array}{l}\text { There were no reviews } \\
\text { found that related } \\
\text { specifically to adding group } \\
\text { members. However, } \\
\text { Meagan Wilters } 06 \text { May } \\
2020 \text {, indicated that she } \\
\text { couldn't chat in the group, 'I } \\
\text { can't chat in any groups'. } \\
\text { This was supported by }\end{array}$ & $\begin{array}{l}\text { There were no positive } \\
\text { reviews found regarding } \\
\text { adding group members. }\end{array}$ \\
\hline
\end{tabular}




\begin{tabular}{|c|c|c|}
\hline & $\begin{array}{l}\text { Mimi ME } 05 \text { February } \\
2020, \text { 'I gave it one star } \\
\text { because it doesn't allow me } \\
\text { to go into any Group chat I } \\
\text { really feel its unfair and } \\
\text { unreasonable' and Jon } \\
\text { Phuti } 15 \text { October } 2019 \\
\text { '...Fix your group chats!!'. } \\
\text { This could indicate a } \\
\text { problem in setting up the } \\
\text { group. }\end{array}$ & \\
\hline $\begin{array}{l}\text { Test 8: } \\
\text { Send a voice } \\
\text { note to a } \\
\text { group }\end{array}$ & $\begin{array}{l}\text { No critical reviews were } \\
\text { found regarding sending } \\
\text { voice notes to groups. } \\
\text { However, there were issues } \\
\text { experienced by users in } \\
\text { terms of chatting, then it } \\
\text { may impact their ability to } \\
\text { send and receive voice } \\
\text { notes too. }\end{array}$ & $\begin{array}{l}\text { Positive reviews on sending } \\
\text { a voice note to a group } \\
\text { were not found. However, } \\
\text { Thembi Zwide } 09 \text { June } \\
2020 \text { indicated that'It's an } \\
\text { amazing app, I love that I } \\
\text { can now record voice notes } \\
\text { and I'm able to correct my } \\
\text { messages. Highly } \\
\text { recommended'. }\end{array}$ \\
\hline $\begin{array}{l}\text { Test 9: } \\
\text { The } \\
\text { application } \\
\text { is available } \\
\text { for use } \\
\text { regardless } \\
\text { of time and } \\
\text { geographica } \\
\text { l location }\end{array}$ & $\begin{array}{l}\text { The following reviews } \\
\text { highlight the need for the } \\
\text { application to have network } \\
\text { connectivity even if it does } \\
\text { not use data to send } \\
\text { messages. Cheryl Phipps } 12 \\
\text { December } 2019 \text { stated, } \\
\text { 'Supposed to be data free, } \\
\text { but messages only come } \\
\text { through when in wifi range' } \\
\text { and Matimba Kubayi } 14 \\
\text { November } 2019 \text {, 'This is a } \\
\text { scam, no matter how many } \\
\text { times I use it nothing goes }\end{array}$ & $\begin{array}{l}\text { Despite this positive review } \\
\text { it still highlights the } \\
\text { dependence on network } \\
\text { connectivity: Sinqobile } \\
\text { Ncube } 11 \text { June } 2020 \text {, 'it is } \\
\text { so good but the network for } \\
\text { Cell c is so bad .its says no } \\
\text { network connection'. The } \\
\text { dependence on network } \\
\text { connectivity may be a } \\
\text { bigger impact on students } \\
\text { in more rural areas. }\end{array}$ \\
\hline
\end{tabular}


through. It needs a constant network connection, it's not \#datafree at all'.

Another scathing review indicated that they would rather pay to use a different instant messenger application, Denise

Stopforth 14 January 2020 'If I could I would have given this app 0 stars. The chat bubbles, the appearance of the chat bubbles, the LIE of the absurd '\#datafree' statement or 'slogan'. Horrible app. You can't even type your own message when a message arrived. This app won't let you. I'll rather buy data and use WhatsApp. I'm disgusted with this app. If something bad happens and you don't have money or data...how do you send photos or voice notes or maybe call for instance????? Get rid of this app, PLEASE'.

Test 10: Analyse data usage
Despite the scathing review by Denise Stopforth, Barry P. Connors 03 June 2020 indicated, '[A] GREAT alternative to Whatsapp. UPDATED: the Moya team is quick to solve any issues that may arise. A great app'.
Despite the critical reviews, Shereen Snyders 21 June 2020 states, 'it's a very helpful app especially when you don't have data'. 


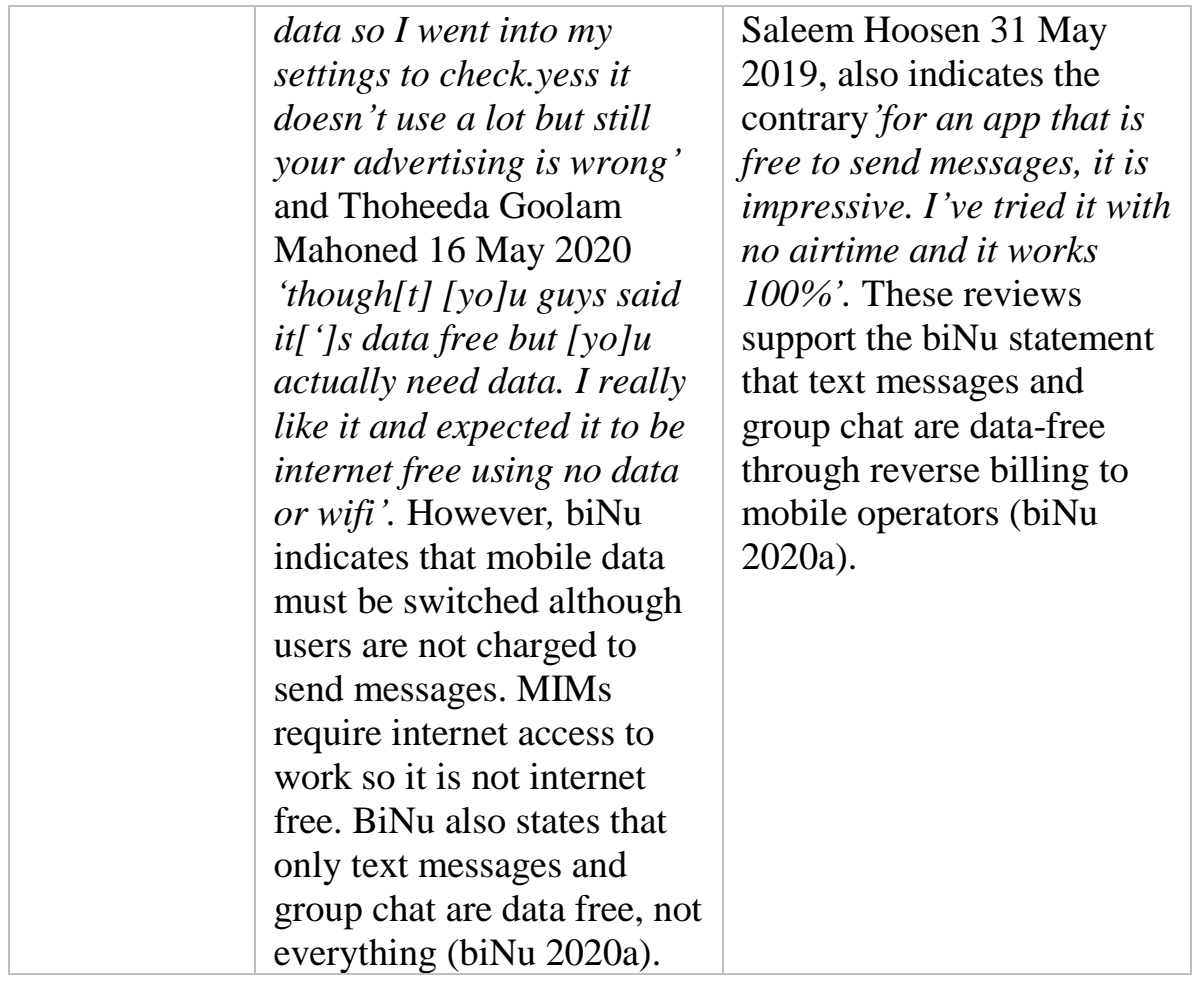

\section{Summary of Results}

Table 3 summarises the results of the ten tests performed. The Moya Messenger application achieved the desired results in $90 \%$ of the tests. The only exception is that mobile data or WiFi needs to be switched on, although no data is required to send text messages. The performance is comparative to the functionality provided by WhatsApp but used comparatively less data. The test results were supported by user reviews from the Google Play store.

Additionally, the use of the Moya Messenger application for students is supported by a reviewer on Google Play store, Thembela Richard Dyongwana 26 March 2020,

Best app ever especially when it comes to information, so wish it can be distributed to all students so that they can create their groups to provide each other with information. Now that there is [a] lockdown 
in RSA why don't all our higher learning facilities use MOYA to give information to their students, it will assist even those that are poor that are living in rural areas (biNu 2020b).

The review is also supported by the following users, Asavela Vela 02 June 2020 ,

It's a very good app because I can search for a job, do online courses for free and today I want to finish what I'm studying and get my certificate, thanks to you guys because some of us can't afford the money to study. Thanks! Thanks! Thanks!!! (biNu 2020b).

\section{Table 3: Summary of Results}

\begin{tabular}{|c|c|c|c|c|}
\hline No & Theme & Test & Test result & $\begin{array}{l}\text { User } \\
\text { reviews }\end{array}$ \\
\hline 1 & Accessibility & $\begin{array}{l}\text { Install the \#datafree } \\
\text { Moya application } \\
\text { from Google Play } \\
\text { store }\end{array}$ & Achieved & Achieved \\
\hline 2 & Accessibility & Complete registration & Achieved & Achieved \\
\hline 3 & Accessibility & $\begin{array}{l}\text { Use the application } \\
\text { with no mobile data } \\
\text { or WiFi switched on }\end{array}$ & $\begin{array}{l}\text { Not } \\
\text { achieved }\end{array}$ & Not achieved \\
\hline 4 & Usability & Send a text message & Achieved & Achieved \\
\hline 5 & Usability & Send an attachment & Achieved & Achieved \\
\hline 6 & Usability & $\begin{array}{l}\text { Create a group for } \\
\text { lecturers }\end{array}$ & Achieved & $\begin{array}{l}\text { Achieved for } \\
\text { other groups }\end{array}$ \\
\hline 7 & $\begin{array}{l}\text { Accessibility } \\
\text { and usability }\end{array}$ & Add group members & Achieved & $\begin{array}{l}\text { Not } \\
\text { explicitly } \\
\text { mentioned }\end{array}$ \\
\hline 8 & Usability & $\begin{array}{l}\text { Send a voice note to a } \\
\text { group }\end{array}$ & Achieved & $\begin{array}{l}\text { Not } \\
\text { explicitly } \\
\text { mentioned }\end{array}$ \\
\hline 9 & $\begin{array}{l}\text { Personalised } \\
\text { learning }\end{array}$ & $\begin{array}{l}\text { The application is } \\
\text { available for use }\end{array}$ & Satisfactory & Satisfactory \\
\hline
\end{tabular}




\begin{tabular}{|l|l|l|l|l|}
\hline & & $\begin{array}{l}\text { regardless of time } \\
\text { and geographical } \\
\text { location }\end{array}$ & & \\
\hline $\mathbf{1 0}$ & Accessibility & Analyse data usage & Satisfactory & Satisfactory \\
\hline
\end{tabular}

These reviews highlight that the application can be used for other activities that may be beneficial to students, especially during the lockdown.

After the initial tests were successfully run among lecturers in two departments and an analysis of Google user reviews completed, a pilot study was implemented in a student group.

\section{Pilot Study}

The Moya Messenger application was piloted in an Accounting course of 495 students and five tutors during the lockdown. The initial test group for the lecturers (refer to test 6) was easy to set up with less than five users. Lecturers had smartphones, data and access to WiFi which may have improved the efficiency of setting up this group. However, the set up for the student group was more difficult and time-consuming when the group size increased. Additionally, the student group were from diverse socioeconomic status and geographical areas. The student group contained students from urban as well as rural areas.

Based on the feedback from the Accounting lecturer, the application was unable to cope with the high number of students who tried to join the group simultaneously. The group was then split smaller groups of 100 students each. Students joined by using the link provided (refer to Figure 10: Create a Group). The link was then sent to each group of 100 students every day. Therefore, the process to create the group for the Accounting course took a week.

Initial feedback from students indicated that iPhone users were excluded due to the application only being available on the Android operating system. However, the tutors and students were able to effectively communicate using the application.

\section{Discussion}

The following section discusses the findings in relation to the research model and the existing literature. 
Subsequent to drafting this article, Network Providers zero-rated the University of the Western Cape's iKamva e-learning platform. Therefore, student access to learning materials was improved. However, students still incurred data costs to use synchronous learning such as BigBlueButton and watching learning materials on external sites, such a YouTube. The lack of synchronous learning may impact student performance in programmes as lecturer engagement during the lockdown is negatively affected.

However, the use of MIMs provides a more cost-effective method to facilitate synchronous and personalised learning. The literature indicates positive student perceptions for using tools, such as MIM, in education. The research model and findings confirm the importance of including accessible tools. The finding is supported by a study conducted in a South African higher education institution using WhatsApp MIM. Using WhatsApp highlights the benefits 'of accessibility, timeliness, quality and relevance of data' in a collaborative learning environment (Ahmad 2020:30).

The use of MIM, such as WhatsApp, is still limited to students who can afford to purchase data. Therefore, the Moya Messenger application may be a more accessible option for students as it requires no data to send text messages. However, the installation of the Moya Messenger application is dependent on having network connectivity. The dependence on network connectivity may be a more important consideration for students in rural areas.

The literature also indicates that MIM, such as WhatsApp, provides an easy to use interface, thus improving usability (Barhoumi 2020). The Moya Messenger application uses a similar interface to WhatsApp. Therefore, the transition to Moya Messenger from WhatsApp should be easier as it builds on students' existing habits of using MIMs. However, user reviews indicate that students may still need some basic training. Training should emphasise that mobile data or WiFi need to be switched on for the Moya Messenger application to work and that not all functionality is data-free.

The ability to set up student groups, despite being more time consuming, grants students the ability to engage with lecturers and fellow students. The data-free group chat will provide engagement that may assist in students' mental health and well-being, especially during the lockdown period. The advantage of Moya Messenger is the additional free functionality, such as searching for jobs and completing online courses. 


\section{Conclusion}

The use of the Moya Messenger was intended to provide an alternative to LMS for all students. Taking institutional-, programme- and individual factors into consideration, the Moya Messenger allows for a usable and accessible option to support personalised learning. However, due to the application only being available on Android mobile devices, iPhone users were excluded. It was found that Moya Messenger was available for download on devices, using Windows 10 operating system. If iPhone users were using this operating instead of a MacBook, then this could provide an alternative method of reaching iPhone users.

The use of Moya Messenger as a data-free alternative to UWC's iKamva LMS would improve if sending attachments were also \#datafree. This would allow items such as lecture slides and assessments to be available to all students, even if they have no available data. However, the application still allows students with low socioeconomic status to engage with their fellow students and lecturers. The engagement will allow students to be kept up to date on University decisions, such as the restarting the academic programme.

The second phase of this study will test students' perceptions of using the Moya Messenger application in the class of 495 Accounting students. The results will provide further insights into whether the application allows for more inclusive design in Higher Education.

\section{Acknowledgements}

The financial assistance of the National Research Foundation (NRF) towards this research is hereby acknowledged. Opinions expressed and conclusions arrived at are those of the author and not necessarily attributable to the NRF. A special note of thanks must be extended to my colleagues, Malcolm Garbutt for finding this application and Ronald Arendse for assisting with tests and piloting it in his course.

\section{References}

Ahmad, T. 2020. Student Perceptions on Using Cell Phones as Learning Tools. PSU Research Review 4,1:25 - 43. https://doi.org/10.1108/PRR-03-2018-0007

Al-Khamisy, D. 2015. Inclusive Education - The Process of Assimilation or 
Emergence? International Journal of Pedagogy, Innovation and New Technologies 2,1: 82 - 89. https://doi.org/10.5604/23920092.1159206

Barhoumi, C. 2020. The Effectiveness of WhatsApp Mobile Learning Activities

Guided by Activity Theory on Students' Knowledge Management. https://doi.org/10.30935/cedtech/6151

biNu 2020a. \#datafree Moya Messenger App. Available at:

https://www.datafree.co/moya-messenger-app (Accessed on 24 April 2020.)

biNu 2020b. Moya Messenger \#datafree. Available at:

https://play.google.com/store/apps/details?id=nu.bi.moya\&hl=en_ZA

(Accessed on 07 July 2020.)

Businesstech 2018. New South African Messaging App doesn't Use Any Data

- But There's a Catch. Available at:

https://businesstech.co.za/news/mobile/264735/new-south-african-

messaging-app-doesnt-use-any-data-but-theres-a-catch/

(Accessed on 24 April 2020.)

Cao, W., Z. Fang, G. Hou, M. Han, X. Xu, J. Dong \& J. Zheng 2020. The

Psychological Impact of the COVID-19 Epidemic on College Students in

China. Psychiatry Research 287.

https://doi.org/10.1016/j.psychres.2020.112934

PMid:32229390 PMCid:PMC7102633

CEICT 2019. EMS: Asynchronous \& Synchronous Engagement and

Simulations to Enhance Learning and Teaching. Available at:

https://www.uwc.ac.za/elearning/News/Pages/EMS-Asynchronous--

Synchronous-Engagement-and-Simulations-to-enhance-Learning-and-

Teaching.aspx (Accessed on 26 April 2020.)

Department: Communications 2012. National e-Skills Plan of Action (NeSPA)

2012. Republic of South Africa.

Department of Education 2001. Special Needs Education: Education White

Paper 6. Pretoria: Government Pritners.

Department of Health: South Africa 2020. COVID-19 South African Online

Portal. Available: https://sacoronavirus.co.za/ (Accesssed on 19 April 2020.)

Department of Telecommunications and Postal Services: Republic of South Africa 2017. South Africa's National e-Strategy.

Fish, L.A. \& C.R. Snodgrass 2018. Instructor Perspectives of Online versus Face-to-Face Education at a Jesuit Institution: Program Factors. The BRC 
Academy Journal of Education 7,1: 15 - 24.

https://doi.org/10.15239/j.brcacadje.2018.07.01.ja03

Friemel, T.N. 2016. The Digital Divide has Grown Old: Determinants of a

Digital Divide among Seniors. New Media and Society 18,2: 313 - 331. https://doi.org/10.1177/1461444814538648

Gillwald, A., O. Mothobi \& B. Rademan 2017. After Access Paper Series: The State of ICT in South Africa. Available at:

https://researchictafrica.net/publication/state-of-ict-in-south-africa/

Gudjonsdottir, H. \& E. Óskarsdóttir 2015. Inclusive Education, Pedagogy and

Practice. In Markic, S. \& S. Abels (eds.): Science Education towards Inclusion. Hauppauge, NY: Nova Science.

Healing, J. 2019. How do SA's Data Prices Compare with the Rest of Africa?

Eyewitness News. Available: https://ewn.co.za/2019/12/03/how-do-sadata-prices-compare-with-the-rest-of-africa (Accessed on 08 July 2020.) Ho, C.S., C.Y. Chee \& R.C. Ho 2020. Mental Health Strategies to Combat the Psychological Impact of COVID-19 Beyond Paranoia and Panic. Annals of the Academy of Medicine, Singapore 49,1: 1 - 3.

https://doi.org/10.47102/annals-acadmedsg.202043

Kemp, S. 2019. Digital 2019: South Africa. Available at:

https://datareportal.com/reports/digital-2019-south-africa

(Accessed on 24 april 2020.)

Khumalo, K. 2020. Manamela Hits out at Wits and Co over Online Learning. Sunday World 19 April. Available at:

https://sundayworld.co.za/news/manamela-hits-out-at-wits-and-co-overonline-learning/ (Accessed on 21 April 2020.)

Koomson, W.K. 2018. Mobile Learning: Application of WhatsApp Messenger as a Learning Tool in a University Distance Learning Program in Ghana. In Proceedings of the 15th International Conference on Cognition and Exploratory Learning in the Digital Age, CELDA 2018. Available at: www.facultyfocus.com (Accecssed on 17 april 2020.)

Lawrie, G., E. Marquis, E. Fuller, T. Newman, M. Qiu, M. Nomikoudis, F. Roelofs \& L. van Dam 2017. Moving towards Inclusive Learning and Teaching: A Synthesis of Recent Literature. Teaching and Learning Inquiry 5,1. https://doi.org/10.20343/teachlearninqu.5.1.3

Meiselwitz, G. \& W.A. Sadera 2008. Investigating the Connection between Usability and Learning Outcomes in Online Learning Environments. MERLOT Journal of Online Learning and Teaching 4,2: 234 - 242. 
Mofokeng, P. 2020. COVID19: UCT Students to Return to Campus in October Wits Vuvuzela. Available: https://witsvuvuzela.com/2020/04/25/covid19uct-students-to-return-to-campus-in-october/

(Accessed on 27 April 2020.)

Moore, J.L., C. Dickson-Deane \& K. Galyen 2011. E-Learning, Online Learning, and Distance Learning Environments: Are they the Same? Internet and Higher Education 14,2: 129 - 135.

https://doi.org/10.1016/j.iheduc.2010.10.001

Morgan, H. \& A.-M. Houghton 2011. Inclusive Curriculum Design in Higher Education: Considerations for Effective Practice Across and Within Subject Areas. UK: The Higher Education Academy. Available at: https://www.heacademy.ac.uk/sites/default/files/resources/introduction_ and_overview.pdf

Myers, M.D. 1997. Qualitative Research in Information Systems. MIS Quarterly 21,2: 241. https://doi.org/10.2307/249422

Mzileni, P. 2020. How Covid-19 will Affect Students. Available at:

https://mg.co.za/education/2020-04-23-how-covid-19-will-affectstudents/ (Accessed on 24 April 2020.)

Nirgude, M. \& A. Naik 2017. WhatsApp Application: An Effective Tool for Out-of-Class Activity. Journal of Engineering Education Transformations 0,0. https://doi.org/10.16920/JEET/2017/V0I0/111759

Nzimande, B. 2020. Government's Intervention Measures on Coronavirus COVID-19. Available at: https://www.gov.za/speeches/response-covid19-24-mar-2020-0000 (Accessed on 20 April 2020.)

Orfanou, K., N. Tselios \& C. Katsanos 2015. Perceived Usability Evaluation of Learning Management Systems: Empirical Evaluation of the System Usability Scale. International Review of Research in Open and Distance Learning 16,2: 227 - 246. https://doi.org/10.19173/irrodl.v16i2.1955

Osguthorpe, R.T. \& C.R. Graham 2003. Blended Learning Environments Definitions and Directions. Quarterly Review of Distance Education 4,3: 227. https://doi.org/10.7765/9781847799005.00014

Pangestu, H. \& M. Karsen 2017. Evaluation of Usability in Online Learning. In Proceedings of 2016 International Conference on Information Management and Technology, ICIMTech 2016. Institute of Electrical and Electronics Engineers Inc.

https://doi.org/10.1109/ICIMTech.2016.7930342

Petersen, F. 2020. Students' Attitude towards Using a Mobile Learning 
Management System: A Large, Undergraduate Information Systems Class. In 2020 Conference on Information Communications Technology and Society. Durban. Available at:

https://www.researchgate.net/publication/340479333 Students' attitude _towards_using_a_mobile_learning_management_system_A_large_und ergraduate_Information_Systems_class (Accessed on 14 April 2020.) Pimmer, C., F. Brühlmann, T.D. Odetola, D. Olusola Oluwasola, O. Dipeolu \& A.J. Ajuwon 2019. Facilitating Professional Mobile Learning Communities with Instant Messaging. Computers \& Education 128: 102 - 112. https://doi.org/10.1016/j.compedu.2018.09.005

Rajgopaul, D. 2019. Data Free Alternative to WhatsApp, Hits One Million Monthly Active Users in SA. Available at:

https://www.iol.co.za/technology/data-free-alternative-to-whatsapp-hitsone-million-monthly-active-users-in-sa-31115674

(Accessed on 24 April 2020.)

Ramaphosa, C. 2020. Extension of Coronavirus COVID-19 Lockdown to the End of April | South African Government. South African Government. Available at: https://www.gov.za/speeches/president-cyril-ramaphosaextension-coronavirus-covid-19-lockdown-end-april-9-apr-2020-0000 (Accessed on 18 April 2020.)

Solomon, P.N. 2017. Technological Usability and Effectiveness of the ELearning System: Evidence from Muni University, Uganda. European Journal of Open Education and E-learning Studies 2,2: 11 - 21.

https://doi.org/10.5281/zenodo.834128

Statistics South Africa 2015. Mbalo Brief - The Missing Piece of the Puzzle. Pretoria: StatsSA.

Statistics South Africa 2018. P0318 - General Household Survey (GHS), 2018. Pretoria: StatsSA.

Stoltenkamp, J. 2019. Centre for Innovative Education and Communication Technologies (CIECT). Available at: https://ciect.wordpress.com/about/ Tang, Y. \& Hew, K.F. 2017. Is Mobile Instant Messaging (MIM) Useful in Education? Examining its Technological, Pedagogical, and Social Affordances. Educational Research Review 21,November 2018: 85 - 104. https://doi.org/10.1016/j.edurev.2017.05.001

The Chronicle of Higher Education 2020. Moving Online Now. Available at: https://engineering.virginia.edu/chronicle-higher-education-movingonline-now 
United Nations 2015. Transforming our World: The 2030 Agenda for Sustainable Development. V. 16301. https://doi.org/10.1007/s13398-0140173-7.2

University of the Western Cape 2019. UWC History. Available at: https://www.uwc.ac.za/about/mission-vision-and-history/history

University of the Western Cape 2020a. \#NoStudentWillBeLeftBehind Champion Page. Available at:

https://www.backabuddy.co.za/champion/project/nswblb

(Accessed on 24 April 2020.)

University of the Western Cape 2020b. About Sakai Help. Available at: https://ikamva.uwc.ac.za/portal/help/main

University of the Western Cape 2020c. Academic Programme. Available at: https://www.uwc.ac.za/Pages/AllProgrammes.aspx

(Accessed on 24 April 2020.)

Venkatesh, V., M.G. Morris, G.B. Davis \& F.D. Davis 2003. User Acceptance of Information Technology: Toward a Unified View. MIS Quarterly. 27,3: 425 - 478. https://doi.org/10.2307/30036540

Walker, L. \& A. Logan 2009. Using Digital Technologies to Promote Inclusive Practices in Education: A Futurelab Handbook. Available at: www.futurelab.org.uk/resources (Accessed on 19 April 2020.)

WhatsApp Inc. Communication 2020. WhatsApp Messenger. Available at: https://play.google.com/store/apps/details?id=com.whatsapp\&hl=en_ZA (Accessed on 08 July 2020.)

Wood, D. 2015. Problematizing the Inclusion Agenda in Higher Education:

Towards a More Inclusive Technology Enhanced Learning Mode. First Monday 20,9. https://doi.org/10.5210/fm.v20i9.6168

World Health Organization 2020. Coronavirus Pandemic. Available at: https://www.who.int/emergencies/diseases/novel-coronavirus-2019 (Accessed on 20 April 2020.)

Fazlyn Petersen Lecturer Department of Information Systems University of the Western Cape Bellville South Africa fapetersen@uwc.ac.za 